\title{
Further evidence for the existence of broiler chicken PFN (pale, firm, non-exudative) and PSE (pale, soft, exudative) meat in brazilian commercial flocks
}

\author{
Leila Moreira de CARVALHO ${ }^{1,2 *}$, Maria Érica da Silva OLIVEIRA ${ }^{1}$, Arlan Silva FREITAS ${ }^{3}$, \\ Arnoud Clementino SOUSA NETO ${ }^{4}$, Elza Iouko IDA ${ }^{5}$, Massami SHIMOKOMAKI ${ }^{6}$, Marta Suely MADRUGA ${ }^{1}$
}

\begin{abstract}
This work aims to investigate the incidence of two color abnormalities in broiler meat: PFN (Pale, Firm, Non-exudative) and PSE (Pale, Soft, Exudative), as well as the physicochemical alterations promoted by those anomalies. The samples of broiler breast meat $(\mathrm{n}=700)$ were classified as $\operatorname{Normal}\left(44<\mathrm{L}^{*}<53, \mathrm{pH}>5.8\right)$, PSE $\left(\mathrm{L}^{*} \geq 53, \mathrm{pH}<5.8\right)$ and $\mathrm{PFN}\left(\mathrm{L}^{*} \geq 53\right.$; $\left.\mathrm{pH}>5.8\right)$. The occurrence of Normal, PSE and PFN samples was $69 \%, 11 \%$ and $20 \%$, respectively. PFN samples presented a $4.2 \%$ higher water-holding capacity compared to PSE meat. PSE meats displayed a higher MFI (89.4) when compared to PFN and Normal meats. It was also noticed that the levels of lipid oxidation were greater in PSE breasts compared to Normal breasts. The total carbonyl in PFN, Normal and PSE meats was $8.2,7.4$ and $5.7 \mathrm{nmol} / \mathrm{mg}$ proteins, respectively. These results confirm the existence of a PFN anomaly in broiler breast meat, which presents functional properties similar to the Normal group. In addition to that, the less firm texture displayed by PSE meats is the result of a greater proteolytic activity, which seems to be related not only to the activation of the calpains, due to the excessive $\mathrm{Ca}^{2+}$, but also to the lower level of protein oxidation.
\end{abstract}

Keywords: abnormal coloration; functional properties; lipid oxidation; protein oxidation.

Practical Application: Data on incidence and characterization of abnormal color meats are important for the prevention and understanding of these anomalies.

\section{Introduction}

The increase in the production of broiler meat, boosted by growing consumer demand, has been reflected in a series of changes in the poultry industry over the last decades. These changes demanded a great deal of effort and intensive genetic selection by producers and breeders, in order to attain an increased growth rate, associated with a better breast muscle yield and better nutritive efficiency. As a result, the birds which are sold nowadays take half the time to grow, and display double the body weight, when compared to birds from the previous six decades (Barbut et al., 2008). However, the selection process implemented, which looks to attain the desired performance in the shortest possible amount of time, has made the animal more susceptible to stress, which in turn leads to a decrease in the quality of its meat (Solomon et al., 1998).

There are countless pre-slaughter factors which are determinant to the quality of meat; among these are: the stress caused by environment factors (temperature, air humidity, thermal radiation and air movement), animal handling conditions, fasting regime and hydric restriction, inadequate handling during loading and unloading of the birds, water showers in farms, transporting conditions, amount of rest and season of the year (Oba et al., 2009; Langer et al., 2010). Moreover, slaughter conditions and post-slaughter processing must also be taken into account (Abdullah \& Matarneh, 2010). Those factors cause physicochemical alterations in the interior of the muscle, which lead to changes in color, $\mathrm{pH}$ and functional properties. In chickens, these changes have been linked to PSE (pale, soft, exudative) and DFD (dark, firm, dry) syndromes (Bianchi et al., 2005).

In relation to pork, in addition to the Normal, PSE and DFD categories, variants of these anomalies have been observed, which have been named PFN (pale, firm, non-exudative) and RSE (reddish-pink, soft, exudative), according to reports by Kauffman et al. (1993). PFN pork displays the firmness and water retention capacity of normal pork, but a pale color similar to PSE. Meanwhile, RSE pork has normal color, but displays a soft texture and an exudative aspect equivalent to PSE meat (Kazemi et al., 2011). In studies carried out in the South of Brazil, a region known for its milder, colder climate, a new anomaly group was detected, related to the color of broiler meat obtained at the processing line. This group was described as having pale color,

${ }^{1}$ Departamento de Engenharia de Alimentos, Universidade Federal da Paraíba - UFPB, João Pessoa, PB, Brasil

${ }^{2}$ Programa de Pós-graduação em Ciência e Tecnologia de Alimentos, Departamento de Engenharia de Alimentos, Centro de Tecnologia, Universidade Federal da Paraíba UFPB, João Pessoa, PB, Brasil

${ }^{3}$ Departamento Acadêmico de Química e Alimentos, Instituto Federal do Maranhão, São Luís, MA, Brasil

${ }^{4}$ Guarabira Aves Ltda - Guaraves, Guarabira, PB, Brasil

${ }^{5}$ Departamento de Ciência e Tecnologia de Alimentos, Universidade Estadual de Londrina - UEL, Londrina, PR, Brasil

${ }^{6}$ Departamento de Ciência Animal, Universidade Estadual de Londrina - UEL, Londrina, PR, Brasil

*Corresponding author: leilamdc@yahoo.com.br 
firm texture and non-exudative aspect, which suggests a new category for broiler meat quality, similar to the one previously reported for pork: PFN (Kaminishikawahara, 2014).

Therefore, considering that the incidence of PFN syndrome in broiler meat and the changes caused by this defect are still not consolidated, this work aims to investigate the incidence of this anomaly and of PSE in broiler meat, as well as the physicochemical alterations provoked by those anomalies, by using animals from a commercial plant in Northeastern Brazil.

\section{Materials and methods}

\subsection{Sample preparation}

This study used broilers of Cobb lineage, of either sex, between 42 and 48 days old. The animals came from a commercial plant located in the town of Guarabira, in the Agreste mesoregion of the State of Paraiba, Northeastern Brazil, with geographical coordinates 6 $6^{\circ} 1^{\prime} 16^{\prime \prime}$ South, 35'29'24" West. Each day, this plant slaughters on average 70,000 birds aged between 42 to 48 days and $2.787 \mathrm{~kg}$ of live weight. Our study was conducted using a sample of $1 \%$ of the total Cobb birds slaughtered in a day, i.e. 700 birds. The experiment was carried out during the rainy season, from May to August 2015. The town of Guarabira lies 97 meters above sea level. The climatic conditions in this region are characterized by a maximum temperature and minimum temperature of 32.1 and $19.5^{\circ} \mathrm{C}$, respectively. The relative humidity $(\mathrm{RH})$ value varied between $80.9 \%$ to $84.7 \%$ during the experiment; the average monthly rainfall for this region is 132.58 millimeters.

The animals were slaughtered according to standard industry practice, consisting of electrical stunning, bleeding, scalding, defeathering, evisceration, pre-chilling through water immersion in two continuous refrigerators. The pre-chiller's temperature was lower than $16^{\circ} \mathrm{C}$, with average duration of 12 minutes, while the chiller's temperature was lower than $4^{\circ} \mathrm{C}$ with average duration of 55 minutes, followed by deboning. After that, the broiler breasts $(\mathrm{n}=700)$ were collected and stored in polyethylene plastic bags and refrigerated at $-3{ }^{\circ} \mathrm{C} \leq \mathrm{T} \leq 2{ }^{\circ} \mathrm{C}$ for 24 hours for subsequent color $\left(\mathrm{L}^{*}\right)$ and $\mathrm{pH}$ measurements and classification.

\subsection{Characterization of broiler breast meat}

The broiler breast meats were classified, according to Soares et al. (2002) and Kaminishikawahara (2014), into three groups: Normal $\left(44<\mathrm{L}^{\star}<53\right.$; $\left.\mathrm{pH}>5.8\right), \mathrm{PFN}\left(\mathrm{L}^{\star} \geq 53\right.$; $\left.\mathrm{pH}>5.8\right)$ and PSE $\left(\mathrm{L}^{*} \geq 53 ; \mathrm{pH}<5.8\right)$. After being classified into one of these three groups, the breasts were characterized according to the following parameters: water-holding capacity, cooking loss, shear force, myofibrillar fragmentation index, protein denaturation, TBARS values, warmed-over flavor, total carbonyl and mineral content $(\mathrm{Ca} 2+, \mathrm{Mg} 2+, \mathrm{K}+$ and $\mathrm{Na}+)$. Given the large number of broiler breasts, as well as the FAO (Food and Agriculture Organization of the United Nations, 1984) guideline recommending that, in such cases, no fewer than 12 (twelve) samples should be gathered and analyzed, the researchers chose to work with 40 (forty) units of Normal breasts, and with 20 (twenty) units each of PFN and PSE breasts. For the analysis of minerals, however, this number was reduced to 12 (twelve) units (Normal group), and 6 (six) units each for the PFN and PSE groups.

\section{Color measurements}

A colorimeter (CR400, Konica Minolta Sensing Inc., Sakai, Osaka, Japan) was used to evaluate the color and lightness $\left(\mathrm{L}^{\star}\right)$ at the dorsal surface of the intact skinless breast muscles, $24 \mathrm{~h}$ post-mortem. The color values were measured in three different areas of the left half of the Pectoralis major muscle: the proximal extremity of the muscle, the distal extremity, and the medial side halfway between the proximal and the distal extremity (Olivo et al., 2001). The results corresponded to the mean of those three areas, and were expressed through the CIELab system.

\section{pH measurements}

The $\mathrm{pH}$ values was measured by inserting electrodes into the ventral cranial part of the fillet using a contact $\mathrm{pH}$ meter system (Testo 205, Testo do Brasil Instrumentos de Medição Ltda, Campinas, São Paulo, Brazil), according to the methodology proposed by Boulianne \& King (1998). Analyses were performed $24 \mathrm{~h}$ post-mortem.

\section{Water-holding capacity (WHC)}

WHC was determined based on the technique described by Hamm (1960). Twenty-four-hour post-mortem samples were collected from the cranial side of the breast meat and cut into $2.0 \mathrm{~g}( \pm 0.10)$ cubes. These were then placed between two filter papers and left under a $10 \mathrm{~kg}$ weight for $5 \mathrm{~min}$. The samples were weighed and WHC was determined by the exudated water weight, via the following formula: $100-\left[\left(\mathrm{W}_{\mathrm{i}}-\mathrm{W}_{\mathrm{f}} / \mathrm{W}_{\mathrm{i}}\right) \mathrm{x} 100\right]$, where $\mathrm{W}_{\mathrm{i}}$ and $\mathrm{W}_{\mathrm{f}}$ are the initial and final sample weights, according to Wilhelm et al. (2010).

\section{Cooking loss (CL)}

CL was expressed as the percentage of water loss during the cooking procedure. It was measured according to Honikel (1998). The samples were cut into two pieces (80 mm length x $30 \mathrm{~mm}$ width x $30 \mathrm{~mm}$ thickness) and weighed. The individual slices were transferred to heat resistant plastic bags, and were placed in a continuously boiling water-bath, with the bag opening extending above the water surface. Samples were cooked until they reached an internal temperature of $75^{\circ} \mathrm{C}$. After that, the samples were cooled in an ice bath $\left(1\right.$ to $\left.5^{\circ} \mathrm{C}\right)$ until attained $30{ }^{\circ} \mathrm{C}$, and the slices were then taken from the bag, blotted dry and weighed.

\section{Shear force measurement (SH)}

Tenderness was evaluated by measuring shear force, as described by Cavitt et al. (2004). It was measured in both raw and cooked breast meat. The samples cooked (or raw) meat were cut $20 \times 20 \times 20 \mathrm{~mm}$ cubes with a thin-bladed sharp knife to minimize damage, and analyzed on a texturometer (TATX-2i texturometer, Stable Microsystems, Godalming, Surrey, UK) with a $50 \mathrm{~kg}$ load cell, penetration depth of $20 \mathrm{~mm}$, test-speed of $10 \mathrm{~mm} / \mathrm{s}$ and trigger force of $10 \mathrm{~g}$. Testing were conducted either perpendicular to the fiber orientation. The results were expressed in Newtons (N). 


\section{Myofibril fragmentation index (MFI)}

MFI was determined according to Culler et al. (1978). Thus, $4 \mathrm{~g}$ of muscle samples, free of external fat and visible connective tissue, were homogenized on an Ultra-turrax (IKA Labortechnix, T25 basic, Wilmington, EUA) in $20 \mathrm{ml}$ of MFI buffer $(100 \mathrm{mM} \mathrm{KCl}$, $20 \mathrm{mM}$ potassium phosphate, $1 \mathrm{mM}$ EDTA, $1 \mathrm{mM} \mathrm{MgCl}_{2}$, and $1 \mathrm{mM} \mathrm{NaN}_{3}$ ) at $\mathrm{pH}$ 7.0. The homogenate was then centrifuged at $10,103 \mathrm{~g}$ for $15 \mathrm{~min}$ at $2{ }^{\circ} \mathrm{C}$. The supernatant was discarded and the pellet was suspended in $20 \mathrm{ml}$ of the MFI buffer and centrifuged at $1000 \mathrm{~g}$ for $15 \mathrm{~min}$ at $2{ }^{\circ} \mathrm{C}$. The resulting supernatant was once more discarded and the pellet was suspended in $10 \mathrm{ml}$ of MFI buffer. The myofibril suspension was filtered to remove connective tissue and assayed for protein concentration using the Biuret method. Suspension aliquots were diluted in MFI buffer until reaching a final protein concentration of $0.5 \mathrm{mg} / \mathrm{ml}$ and then poured into a cuvette for immediate absorbance measurement at $540 \mathrm{~nm}$ with a spectrophotometer (Quimis Q898-U, São Paulo, Brazil). The MFI was expressed as $A_{540 \mathrm{~nm}} \times 200$.

\section{Protein denaturation (PD)}

PD was determined according to Swatland (1995). The samples were weighed $(5 \mathrm{~g})$ and homogenized with $15 \mathrm{~mL}$ of distilled water, then were centrifuged for $15 \mathrm{~min}$ at $9150 \mathrm{rpm}$. The suspension was filtered and $1 \mathrm{~mL}$ was diluted in $5 \mathrm{~mL}$ of $0,02 \mathrm{M}$ citrate-phosphate buffer $\mathrm{pH} 4.6$ (solution 1). Another aliquot of the filtrate $(1 \mathrm{~mL}$ ) was diluted in $5 \mathrm{~mL}$ of distilled water (solution 2). The solutions were placed in a water bath $\left(20 \pm 2{ }^{\circ} \mathrm{C}\right)$ for $30 \mathrm{~min}$. The PD was estimated by using the difference between the transmittance readings for solution 2 and for solution 1 at $600 \mathrm{~nm}$.

\section{Mineral content}

The quantification of mineral elements $\left(\mathrm{Ca}^{2+}, \mathrm{Mg}^{2+}, \mathrm{K}^{+}\right.$and $\left.\mathrm{Na}^{+}\right)$ was performed based on the official AOAC methods (Association of Official Analytical Chemists, 2000) using Inductively Coupled Plasma-Optical Emission Spectroscopy (ICP-OES, Varian Inc. 720-ES, Walnut Creek, California, USA). The system was totally controlled by ICP software using 99.996\% liquid argon as plasma gas (Air Liquid, SP, Brazil). Operating conditions of the ICP-OES equipment were: reflected power, $1.0 \mathrm{~kW}$; spray flow, $0.9 \mathrm{Lmin}^{-1}$; auxiliary argon flow, $1.5 \mathrm{Lmin}^{-1}$; main argon flow, $15 \mathrm{~L} \mathrm{~min}^{-1}$; nebulizer pressure, $200 \mathrm{kPa}$. This analysis was performed in the Soils Laboratory of the Agrarian Sciences Center, at Maranhão State University.

Total fat

The total fat was determined by following Folch et al. (1957) methodology.

\section{TBARS numbers}

Thiobarbituric acid reactive substances were determined for both raw and cooked samples of all three groups (Normal, PFN and PSE), according to the method of Rosmini et al. (1996). The results were expressed as $\mathrm{mg} \mathrm{MDA} / \mathrm{kg}$ sample.

\section{Warmed-over flavor (WOF)}

WOF was determined according to Soares et al. (2004) with adaptations. Samples were vacuum packed and cooked in water bath until reaching an internal temperature of $75^{\circ} \mathrm{C}$, and then stored at $4{ }^{\circ} \mathrm{C}$ for $48 \mathrm{~h}$ under fluorescent light. After that, the samples were re-heated in water bath at $85^{\circ} \mathrm{C}$ for $15 \mathrm{~min}$, and left to cool to room temperature; the WOF which resulted from this procedure was then determined by measuring the TBARS numbers, following the technique described by Rosmini et al. (1996).

\section{Total carbonyl content}

Protein oxidation was measured by determining the total carbonyl content, according to the DNPH method adapted by Oliver et al. (1987). The total carbonyl content was measured in a spectrophotometer (Quimis Q898-U, São Paulo, Brazil) at $370 \mathrm{~nm}$. The protein content was in turn determined by using the Kjeldahl method according to AOAC (Association of Official Analytical Chemists, 2000). The results were expressed as $\mathrm{nM} / \mathrm{mg}$ protein.

\section{Statistical analysis}

Data were submitted to analysis of variance (ANOVA) and the means were compared through the Tukey test. Assistat (Assistat - Statistical Assistance Software, version beta 7.7, Campina Grande, Paraíba, Brazil) statistic software was used to perform statistical analysis and data correlation. The resulting graph was generated by using GraphPad Prism software (GraphPad Prism version 6.0 for Windows, Graphpad Software Inc., San Diego, California, USA).

\section{Results and discussion}

\subsection{Incidence of broiler breasts with abnormal coloration}

The incidence of broiler breast meat (Figure 1) with abnormal coloring was higher than $30 \%$; PFN breasts $(n=140)$ accounted for $20 \%$, while PSE breasts $(n=77)$ accounted for $11 \%$. Normal meat accounted for $69 \%$ of total breasts $(n=483)$.

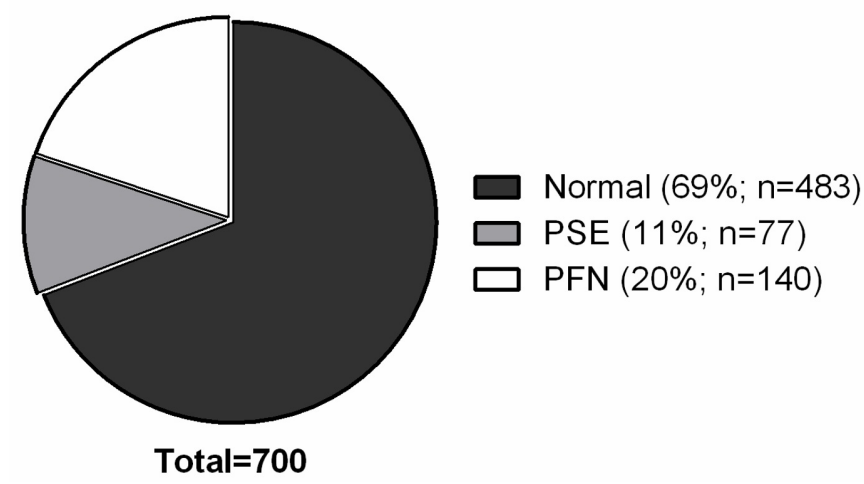

Figure 1. Incidence of broiler breasts with abnormal coloration (PSE, PFN) in Northeastern Brazil. PFN: Pale, Firm, Non-Exudative; PSE: Pale, Soft, Exudative. 
In the USA, Woelfel et al. (2002) reported that $47 \%$ of the broiler meat evaluated displayed a pale color and lower WHC values. Meanwhile, in the South of Brazil, Soares et al. (2002) and Droval et al. (2012) reported PSE percentages of $12 \%$ and 22\% respectively. Furthermore, in Southern Brazil Simões et al. (2009) observed that, the longer the distance and journey time for chickens, the higher the occurrence of PSE. In addition to this, it was also confirmed that water showers in chicken farms helped to reduce PSE occurrence.

Recently, the occurrence of PSE and DFD in broiler meat was reported in Northeast region of Brazil during two-season: dry (summer) and rainy (winter) season. PSE meat results were $43.53 \%$ and $10.46 \%$, respectively, while $3,3 \%$ of DFD meat only observed in the rainy season (Freitas et al., 2017).

Obviously, the high occurrence of PSE is due to the thermal stress conditions to which the birds are subjected during handling as recently observed (Freitas et al., 2016). According to Oba et al. (2009), the presence of PSE syndrome may be due to the effects of high temperatures and relative humidity. These conditions are typical of the summer in Southern Brazil, but are also predominant in the Agreste mesoregion of the state of Paraiba, Northeastern Brazil. Therefore, the lower incidence of PSE observed in Northeastern Brazil may be associated with the time of the year in which the breasts were collected - as stated earlier, in this study they were gathered during the rainy season, which is characterized by its milder temperatures $\left(20^{\circ} \mathrm{C}\right)$. Furthermore, various researchers (Langer et al., 2010; Mccurdy et al., 1996) observed that seasonal differences increased the occurrence of pale meats, suggesting that thermal stress during the summer led to a higher rate of PSE syndrome in birds. The same was also observed in pigs (Santos et al., 1994).

As for the PFN anomaly, Kaminishikawahara (2014) reported that broiler breast meat from Southern Brazil had a PFN incidence of $85.7 \%$, and a PSE incidence of $9.1 \%$. This is the first time, however, that a PFN anomaly has been reported in broilers from Northeastern Brazil.

\subsection{Characterization of broiler breast}

The physical parameters and the functional properties of Normal, PSE and PFN breast meat are presented in Table 1. The PFN group had a lower $\mathrm{pH}$ than the Normal group, but it was still higher than the $\mathrm{pH}$ displayed by the PSE group. Moreover, there was no difference in color between PFN and PSE values, and both displayed a higher $\mathrm{L}_{24 \mathrm{~h}}$ value than Normal breast meat.

Normal and PFN breasts had similar WHC values, which in turn were $4.2 \%$ higher than the one displayed by PSE breasts. This result is in accordance with what was reported by Kaminishikawahara (2014). According to Huff-Lonergan \& Lonergan (2005), the accelerated $\mathrm{pH}$ decline and low ultimate $\mathrm{pH}$ are related to the development of low water-holding capacity. Rapid $\mathrm{pH}$ decline while the muscle temperature is still high causes the proteins denaturation, including those involved in binding water. The authors emphasize that the most severe water or drip loss is normally found in PSE condition.
Table 1. Comparison of biochemical and chemical parameters between Normal, PFN and PSE broiler breast (Pectoralis major muscle), from the Northeastern region of Brazil.

\begin{tabular}{cccc}
\hline Parameters & Normal $(\mathrm{n}=40)$ & PFN $(\mathrm{n}=20)$ & PSE $(\mathrm{n}=20)$ \\
\hline $\mathrm{pH}_{24 \mathrm{~h}}$ & $6.13 \pm 0.22^{\mathrm{a}}$ & $5.93 \pm 0.05^{\mathrm{b}}$ & $5.70 \pm 0.04^{\mathrm{c}}$ \\
$\mathrm{L}^{*}{ }_{24 \mathrm{~h}}$ & $47.90 \pm 2.10^{\mathrm{b}}$ & $55.07 \pm 0.91^{\mathrm{a}}$ & $55.04 \pm 0.78^{\mathrm{a}}$ \\
$\mathrm{a}^{*}{ }_{24 \mathrm{~h}}$ & $0.71 \pm 0.64$ & $0.82 \pm 0.59$ & $1.14 \pm 0.68$ \\
$\mathrm{~b}^{*}{ }_{24 \mathrm{~h}}$ & $5.24 \pm 1.94$ & $6.30 \pm 1.34$ & $6.19 \pm 1.50$ \\
$\mathrm{WHC} \%)$ & $67.02 \pm 2.57^{\mathrm{a}}$ & $66.90 \pm 1.98^{\mathrm{a}}$ & $64.21 \pm 1.86^{\mathrm{b}}$ \\
$\mathrm{CL}(\%)$ & $13.66 \pm 1.63^{\mathrm{b}}$ & $15.19 \pm 3.13^{\mathrm{ab}}$ & $16.18 \pm 2.05^{\mathrm{a}}$ \\
$\mathrm{SF}_{\text {raw }}(\mathrm{N})$ & $39.03 \pm 5.78^{\mathrm{ab}}$ & $42.43 \pm 6.70^{\mathrm{a}}$ & $35.21 \pm 6.57^{\mathrm{b}}$ \\
$\mathrm{SF}_{\text {cooked }}(\mathrm{N})$ & $23.45 \pm 4.30^{\mathrm{b}}$ & $26.38 \pm 4.58^{\mathrm{ab}}$ & $27.34 \pm 4.58^{\mathrm{a}}$ \\
$\mathrm{MFI}$ & $83.46 \pm 4.53^{\mathrm{b}}$ & $84.61 \pm 3.88^{\mathrm{b}}$ & $89.37 \pm 3.88^{\mathrm{a}}$ \\
$\mathrm{PD}_{\text {fresh }}(\%)$ & $21.19 \pm 8.66$ & $25.53 \pm 11.33$ & $27.62 \pm 9.10$ \\
$\mathrm{PD}_{\text {frozen }}(\%)$ & $34.37 \pm 11.97$ & $36.82 \pm 15.23$ & $36.94 \pm 17.35$ \\
$\mathrm{Mineral} \mathrm{content}(\mathrm{n}=12)$ & $(\mathrm{n}=6)$ & $(\mathrm{n}=6)$ \\
$\mathrm{Ca}^{2+}(\mathrm{mg} / \mathrm{kg})$ & $462 \pm 26.8^{\mathrm{b}}$ & $373 \pm 43.3^{\mathrm{c}}$ & $531 \pm 28.2^{\mathrm{a}}$ \\
$\mathrm{K}^{+}(\mathrm{mg} / \mathrm{kg})$ & $4987 \pm 171.6$ & $4762 \pm 82.8$ & $5000 \pm 159.5$ \\
$\mathrm{Mg}^{2+}(\mathrm{mg} / \mathrm{kg})$ & $936 \pm 29.9$ & $929 \pm 17.5$ & $949 \pm 67.4$ \\
$\mathrm{Na}^{+}(\mathrm{mg} / \mathrm{kg})$ & $1208 \pm 244.8$ & $1305 \pm 83.0$ & $1219 \pm 65.0$ \\
\hline
\end{tabular}

a-b-c Means within each line with different superscripts are significantly different $(\mathrm{p}<0.05)$. PFN: Pale, Firm, Non-Exudative; PSE: Pale, Soft, Exudative; $\mathrm{pH}_{24 \mathrm{~h}}$ : $\mathrm{pH}$ values measured $24 \mathrm{~h}$ post-mortem; $\mathrm{L}^{*}$ : lightness; $\mathrm{a}^{*}$ : redness; $\mathrm{b}^{*}$ : yellowness; WHC: water-holding capacity; CL: cooking loss; $\mathrm{SF}_{\text {raw: }}$ Shear Force raw meat; $\mathrm{SF}_{\text {cooked }}$ : Shear Force cooked meat; MFI: Myofibrillar fragmentation index; $\mathrm{PD}_{\text {fresh }}$ : Protein denaturation values of fresh tissue; $\mathrm{PD}_{\text {frozen }}:$ Protein denaturation values of frozen tissue.

As for CL levels, the highest values were observed in the PSE compared to Normal group, indicating that these samples were more susceptible to heat, and thus when submitted to heating, ended up losing more weight. The CL value in PSE breasts was $18.4 \%$ higher than in Normal breasts; however, this percentage still was not as high as the $31 \%$ reported by Droval et al. (2012). PFN meat displayed CL values which were statistically similar to the ones shown by PSE and Normal breasts.

The shear force values of raw PFN meat did not differ from those of raw Normal meat, but were 21\% higher than the ones displayed by raw PSE meat. This shows that PSE breasts had less firmness compared to PFN group, which is in conformity with the results noted by Kaminishikawahara (2014). Wilhelm et al. (2010) observed that the intense protease activity in PSE meats, caused by the excessive release of sarcoplasmic $\mathrm{Ca}^{2+}$ ions, ended up affecting the muscular fiber structure and impairing the functionality of meat proteins, and, as a consequence, led to a loss of texture. However, the SF of raw Normal meat and raw PSE meat did not significantly differ from one another, and were similar to what was reported by Droval et al. (2012).

On the other hand, when measuring shear force in cooked breast, it was observed that PSE meat displayed 16.6\% higher SF than Normal meat. The firmest texture was observed in the PSE cooked breast, which resulted in a lower WHC and higher CL. SF in PFN breasts were no different from the normal group.

PSE meat presented a higher MFI ( $p>0.05)$ than PFN and Normal meat (Table 1). It was also noted that the MFI of PFN 
meat was 5.3\% lower in relation to PSE meat, and did not differ $(p<0.05)$ from the Normal meat; this is likely the consequence of a lower proteolytic activity in PFN and Normal meat. According to Wilhelm et al. (2010), the PSE group presented a higher MFI compared to Normal meat and this is in accordance with the data observed in this study. As was reported by Purchas (2014), the action of the calpains and cathepsins enzymes on meat proteins during the post-mortem period is determinant for the final tenderness of the meat, since they degrade myofibrillar proteins and thus make the meat tenderer. There was no significant difference $(\mathrm{p}<0.05)$ between the protein denaturation values measured for PFN, PSE and Normal broiler breast meat.

The mineral content of Normal, PSE and PFN breasts is presented in Table 1 . The calcium levels differed $(\mathrm{p}<0.001)$ from one group to the other; PFN meat had the lowest concentration, followed by Normal meat. PSE meat displayed the highest calcium level of all three: $42.3 \%$ higher than PFN meat and $14.9 \%$ higher than Normal meat. These results are in accordance with literature, which links higher calcium levels to the lower $\mathrm{pH}$ presented by this meat. Mickelson \& Louis (1996) described a deficiency in calcium regulation in pigs submitted to stressor agents, in which they observed a mutation in the ryanodine (RyR1) receptor - which belongs to the calcium channel in the sarcoplasmic reticulum - being responsible for a greater availability of these ions. This excessive amount of $\mathrm{Ca}^{2+}$ ions accelerated metabolism and thus increased the pace at which the $\mathrm{pH}$ declined. In chickens, Oda et al. (2009) reported lower mean relative quantification (RQ) values for the $\beta$-RyR gene expression in PSE broiler breast meat, with this being the first sign of PSE syndrome occurring as a result of the excessive release of calcium ions. According to Lee et al. (2008) calpains are enzymes involved in post-mortem proteolysis and in the tenderness process. These enzymes are also calcium sensitive, which may explain the larger MFI observed in PSE meat (Table 1).

No significant differences $(p>0.05)$ were observed in the magnesium, sodium and potassium levels of Normal, PSE and PFN breast meat.

Correlation between the different parameters, such as $\mathrm{pH}$, $\mathrm{L}^{*}, \mathrm{WHC}, \mathrm{CL}$ and SF raw and SF cooked meat are presented in Table 2. The following negative and significant correlations were observed: between $\mathrm{pH}$ and lightness $(\mathrm{r}=-0.8095)$; between $\mathrm{pH}$ and $\mathrm{CL}(\mathrm{r}=-0.5220)$; between $\mathrm{pH}$ and SF cooked sample $(r=-0.4530)$. The positive and significant correlations noted were: between $\mathrm{pH}$ and WHC $(\mathrm{r}=0.4892)$ and between $\mathrm{pH}$ and $\mathrm{SF}$ raw sample $(\mathrm{r}=0.2938)$. These results confirm that the lower the $\mathrm{pH}$, the greater the impairment in functional properties of the meat.

Although PFN meat presented a $L^{*}$ value similar to that of PSE meat, the results (Table 1) show that the PFN group is more similar to the Normal than to the PSE group. This can be observed by looking at the values shown for WHC, CL, SF and MFI.

No differences were observed in the WOF and TBARS values displayed by the cooked breasts of the three groups (Table 3 ). Meanwhile, TBARS values for raw PSE meat did not differ from those of raw PFN meat, but were $44 \%$ larger when compared to Normal meat. Kaminishikawahara (2014) observed that PSE meat displayed $48 \%$ higher lipid oxidation than Normal meat. Carvalho et al. (2017) observed higher TBARS numbers in PSE-induced breasts. According to these results, the PSE meat suffer more intense lipid oxidative reaction than in normal meat. Metabolic alterations occurs in animals as a response to their adaptation to heat stress, affecting the balance between antioxidants and free radical by increasing the generation of free radicals. These radicals exhibit adverse effects, such as lipid peroxidation (Imik et al., 2012). In broilers the heat stress increases the mitochondrial ROS that may lead to modification in lipids, proteins, and nucleic acids besides causing oxidative damage (Mujahid et al., 2007).

In relation to total carbonyl content, PFN meat did not differ from Normal meat. However, when compared to PSE meat, PFN meat had $44.2 \%$ higher carbonyl content, while no differences were observed between Normal group (Table 3). This indicates that PFN meat were more susceptible to protein oxidation when compared to PSE meat. Protein oxidation promotes chemical modifications in specific amino acid side chains and/or in polypeptides chains, thus altering the physical characteristics of the myofibrillar proteins. It can also cause the inactivation of proteolytic enzymes involved in the meat tenderization process. All of this leads to a decrease in the proteolytic susceptibility (Carlin et al., 2006). This explains the lower proteolytic activity (MFI) observed in PFN and Normal meats, which gave them a firmer texture in relation to PSE meat (Table 1).

Table 2. Correlation between $\mathrm{pH}, \mathrm{L}^{\star}, \mathrm{WHC}, \mathrm{CL}$ and SF of PFN, PSE and Normal broiler breast (Pectoralis major muscle), from Northeastern Brazil.

\begin{tabular}{ccccccc}
\hline Parameters & $\mathrm{pH}_{24 \mathrm{~h}}$ & $\mathrm{~L}^{*}$ & $\mathrm{WHC}$ & $\mathrm{CL}$ & $\mathrm{SF}_{\text {raw }}$ & $\mathrm{SF}_{\text {cooked }}$ \\
\hline $\mathrm{pH}_{24 \mathrm{~h}}$ & 1 & $-0.8095^{*}$ & $0.4892^{*}$ & $-0.5220^{*}$ & $0.2938^{*}$ & $-0.4530^{*}$ \\
$\mathrm{~L}^{*}$ & & 1 & $-0.2930^{*}$ & $0.4706^{*}$ & $\mathrm{~ns}$ & $0.4391^{*}$ \\
$\mathrm{WHC}$ & & & 1 & $\mathrm{~ns}$ & $0.3196^{*}$ & $-0.2790^{*}$ \\
$\mathrm{CL}$ & & & & 1 & $\mathrm{~ns}$ & $-0.2570^{*}$ \\
$\mathrm{SF}_{\text {raw }}$ & & & & & 1 & $\mathrm{~ns}$ \\
$\mathrm{SF}_{\text {cooked }}$ & & & & & & 1
\end{tabular}

* significant level at probability of $5 \%(\mathrm{p}<0.05)$; ns - non significant; $\mathrm{pH}_{24 \mathrm{~h}}$ : $\mathrm{pH}$ values measured $24 \mathrm{~h}$ post-mortem; L*: lightness; WHC: water-holding capacity; CL: cooking loss; $\mathrm{SF}_{\text {raw }}$ : Shear Force raw meat; $\mathrm{SF}_{\text {cooked }}$ : Shear Force cooked meat.

Table 3. Lipid and protein oxidation of PFN, PSE and Normal broiler breast (Pectoralis major).

\begin{tabular}{lccc}
\hline \multicolumn{1}{c}{ Parameters } & Normal $(\mathrm{n}=40)$ & PFN $(\mathrm{n}=20)$ & PSE $(\mathrm{n}=20)$ \\
\hline Lipid content $^{1}$ & $2.93 \pm 0.21$ & $2.92 \pm 0.22$ & $2.98 \pm 0.26$ \\
Lipid oxidation & & & \\
TBARSraw & $0.18 \pm 0.04^{\mathrm{b}}$ & $0.23 \pm 0.05^{\mathrm{ab}}$ & $0.26 \pm 0.07^{\mathrm{a}}$ \\
TBARScooked & $0.40 \pm 0.08$ & $0.42 \pm 0.17$ & $0.40 \pm 0.13$ \\
WOF & $1.26 \pm 0.13$ & $1.30 \pm 0.12$ & $1.31 \pm 0.17$
\end{tabular}

Protein

oxidation

Protein content $^{1} \quad 25.96 \pm 1.60 \quad 27.47 \pm 1.99 \quad 27.81 \pm 1.48$

Total carbonyl $^{3} \quad 7.44 \pm 2.40^{\mathrm{ab}} \quad 8.22 \pm 1.14^{\mathrm{a}} \quad 5.70 \pm 1.58^{\mathrm{b}}$

${ }^{a-b}$ Means within each line with different superscripts are significantly different $(\mathrm{p}<0.05)$; PFN: Pale, Firm, Non-Exudative; PSE: Pale, Soft, Exudative; ${ }^{1} \mathrm{~g} / 100 \mathrm{~g}$ tissue; ${ }^{2} \mathrm{mg} \mathrm{MDA} / \mathrm{kg}$ tissue; ${ }^{3} \mathrm{nmol}$ carbonyls/mg protein. TBARSraw or cooked: Thiobarbituric acid reactive substances on raw or cooked tissue; TBARScooked: Thiobarbituric acid reactive substances on cooked tissue; WOF - Warmed-over flavor. 
Table 4. Correlation between total carbonyl, MFI and SF of PFN, PSE and Normal broiler breast (Pectoralis major muscle), from Northeastern Brazil.

\begin{tabular}{ccccc}
\hline Parameters & $\begin{array}{c}\text { Total } \\
\text { carbonyl }\end{array}$ & MFI & $\mathrm{SF}_{\text {raw }}$ & $\mathrm{SF}_{\text {cooked }}$ \\
\hline Total carbonyl & 1 & $\mathrm{~ns}$ & $0.5998^{*}$ & $\mathrm{~ns}$ \\
$\mathrm{MFI}$ & & 1 & $\mathrm{~ns}$ & $\mathrm{~ns}$ \\
$\mathrm{SF}_{\text {raw }}$ & & & 1 & $\mathrm{~ns}$ \\
$\mathrm{SF}_{\text {cooked }}$ & & & & 1 \\
\hline
\end{tabular}

*significant level at probability of 5\% $(\mathrm{p}<0.05)$; ns - non significant; PFN: Pale, Firm, Non-Exudative; PSE: Pale, Soft, Exudative; MFI: Myofibrillar fragmentation index; $\mathrm{SF}_{\text {raw }}$ : Shear Force raw meat; $\mathrm{SF}_{\text {cooked }}$ : Shear Force cooked meat.

Correlation between Total carbonyl content, MFI, SF raw and SF cooked meat are presented in Table 4. The significant and positive correlations were observed between total carbonyl content and SF raw $(r=0.5998)$. This result confirms that the higher level of protein oxidations in meat leads to a firmer texture.

\section{Conclusion}

This work confirmed the existence of an emerging group of abnormal color in broiler meat: PFN (pale, firm, non-exudative). However, the functional properties of PFN meat were similar to those shown by the Normal group. In addition to that, the results reported confirm that the PSE syndrome in broilers is related to a flaw in calcium regulation, which led to a decrease in meat $\mathrm{pH}$, and thus compromised functional properties. Besides, the less firm texture observed in PSE broiler results from the greater proteolytic activity, which seems to be related not only to the activation of the calpains, due to the excessive calcium ions, but also to the smaller level of protein oxidation.

\section{Acknowledgements}

The authors gratefully acknowledge the financial support of CNPq - Conselho Nacional de Desenvolvimento Científico e Tecnológico, Process 483047/2013-9, and the Guaraves Guarabira Aves Ltda by donation of broiler breast meat.

\section{References}

Abdullah, A. Y., \& Matarneh, S. K. (2010). Broiler performance and the effects of carcass weight, broiler sex, and postchill carcass aging duration on breast fillet quality characteristics. Journal of Applied Poultry Research, 19(1), 46-58. http://dx.doi.org/10.3382/ japr.2009-00079.

Association of Official Analytical Chemists - AOAC. (2000). Official methods of analysis of official analytical chemists (17th ed.). Washington, DC.

Barbut, S., Sosnicki, A. A., Lonergan, S. M., Knapp, T., Ciobanu, D. C., Gatcliffe, L. J., Huff-Lonergan, E., \& Wilson, E. W. (2008). Progress in reducing the pale, soft and exudative (PSE) problem in pork and poultry meat. Meat Science, 79(1), 46-63. http://dx.doi.org/10.1016/j. meatsci.2007.07.031. PMid:22062597.

Bianchi, M., Fletcher, D. L., \& Smith, D. P. (2005). Physical and functional properties of intact and ground pale broiler breast meat. Poultry
Science, 84(5), 803-808. http://dx.doi.org/10.1093/ps/84.5.803. PMid:15913194.

Boulianne, M., \& King, J. (1998). Meat color and biochemical characteristics of unacceptable Dark-colored broiler chicken carcasses. Journal of Food Science, 63(5), 759-762. http://dx.doi. org/10.1111/j.1365-2621.1998.tb17894.x.

Carlin, K. R. M., Huff-Lonergan, E., Rowe, L. J., \& Lonergan, S. M. (2006). Effect of oxidation, $\mathrm{pH}$, and ionic strength on calpastatin inhibition of $\mu$ - and m-calpain. Journal of Animal Science, 84(4), 925-937. http://dx.doi.org/10.2527/2006.844925x. PMid:16543571.

Carvalho, R. H., Ida, E. I., Madruga, M. S., Martínez, S. L., Shimokomaki, M., \& Estévez, M. (2017). Underlying connections between the redox system imbalance, protein oxidation and impaired quality traits in pale, soft and exudative (PSE) poultry meat. Food Chemistry, 215, 129-137. http://dx.doi.org/10.1016/j.foodchem.2016.07.182. PMid:27542459.

Cavitt, L. C., Youm, G. W., Meullenet, J. F., Owens, C. M., \& Xiong, R. (2004). Prediction of poultry meat tenderness using razor Blade Shear, Allo-Kramer Shear, and sarcomere length. Journal of Food Science, 69(1), SNQ11-SNQ15. http://dx.doi.org/10.1111/j.1365-2621.2004. tb17879.x.

Culler, R. D., Parrish, F. C. Jr., Smith, G. C., \& Cross, H. R. (1978). Relationship of myofibril fragmentation index to certain chemical, physical and sensory characteristics of bovine Longisimus muscle. Journal of Food Science, 43(4), 1177-1180. http://dx.doi. org/10.1111/j.1365-2621.1978.tb15263.x.

Droval, A. A., Benassi, V. T., Rossa, A., Prudencio, S. H., Paião, F. G., \& Shimokomaki, M. (2012). Consumer attitudes and preferences regarding pale, soft, and exudative broiler breast meat. Journal of Applied Poultry Research, 21(3), 502-507.http://dx.doi.org/10.3382/ japr.2011-00392.

Folch, J., Lees, M., \& Sloane Stanley, G. H. (1957). A simple method for the isolation and purification of total lipids from animal tissues. The Journal of Biological Chemistry, 226(1), 497-509. PMid:13428781.

Food and Agriculture Organization of the United Nations - FAO. (1984). FAO Food and Nutrition (Papers 14/5 - Food inspection). Rome: FAO.

Freitas, A. S., Carvalho, L. M., Soares, A. L., Oliveira, M. E. S., Madruga, M. S., Sousa, A. C. No., Carvalho, R. H., Ida, E. I., \& Shimokomaki, M. (2016). Simultaneous occurrence of broiler chicken hyper and hypothermia in-transit and lairage and dead on arrival (DOA) index under tropical climate. International Journal of Poultry Science, 15(11), 459-466. http://dx.doi.org/10.3923/ijps.2016.459.466.

Freitas, A. S., Carvalho, L. M., Soares, A. L., Oliveira, M. E. S., Madruga, M. S., Sousa, A. C. No., Carvalho, R. H., Ida, E. I., \& Shimokomaki, M. (2017). Pale, soft and exudative (PSE) and dark, firm and dry (DFD) meat determination in broiler chicken raised under tropical climate management conditions. International Journal of Poultry Science, 16(3), 81-87. http://dx.doi.org/10.3923/ijps.2017.81.87.

Hamm, R. (1960). Biochemistry of meat hydration. Advances in Food Research, 10, 355-463. http://dx.doi.org/10.1016/S00652628(08)60141-X. PMid:13711042.

Honikel, K. O. (1998). Reference methods for the assessment of physical characteristics of meat. Meat Science, 49(4), 447-457. http://dx.doi. org/10.1016/S0309-1740(98)00034-5. PMid:22060626.

Huff-Lonergan, E., \& Lonergan, S. M. (2005). Mechanisms of waterholding capacity of meat: the role of postmortem biochemical and structural changes. Meat Science, 71(1), 194-204. http://dx.doi. org/10.1016/j.meatsci.2005.04.022. PMid:22064064. 
Imik, H., Ozlu, H., Gumus, R., Atasever, M. A., Urcar, S., \& Atasever, M. (2012). Effects of ascorbic acid and $\alpha$-lipoic acid on performance and meat quality of broilers subjected to heat stress. British Poultry Science, 53(6), 800-808. http://dx.doi.org/10.1080/00071668.2012. 740615. PMid:23398425.

Kaminishikawahara, C. M. (2014). Caracterização bioquímica e estrutural de filés de frango análogo ao PFN (pale, firm, non-exudative) e PSE (pale, soft, exudative) (Master's thesis). Universidade Estadual de Londrina, Londrina.

Kauffman, R. G., Cassens, R. G., Scherer, A., \& Meeker, D. L. (1993). Variations in pork quality: History, definition, extent, resolution. Swine Health and Production, 1, 28-34.

Kazemi, S., Ngadi, M. O., \& Gariepy, C. (2011). Protein denaturation in Pork Longissimus Muscle of different quality groups. Food and Bioprocess Technology, 4(1), 102-106. http://dx.doi.org/10.1007/ s11947-009-0201-3.

Langer, R. O. S., Simões, G. S., Soares, A. L., Oba, A., Rossa, A., Shimokomaki, M., \& Ida, E. I. (2010). Broiler Transportation Conditions in a Brazilian Commercial Line and the Occurrence of Breast PSE (Pale, Soft, Exudative) Meat and DFD-like (Dark, Firm, Dry) Meat. Brazilian Archives of Biology and Technology, 53(5), 1161-1167. http://dx.doi.org/10.1590/S1516-89132010000500021.

Lee, H. L., Santé-Lhoutellier, V., Vigouroux, S., Briand, Y., \& Briand, M. (2008). Role of calpains in postmortem proteolysis in chicken muscle. Poultry Science, 87(10), 2126-2132. http://dx.doi.org/10.3382/ ps.2007-00296. PMid:18809876.

Mccurdy, R. D., Barbut, S., \& Quinton, M. (1996). Seasonal effect on pale soft exudative (PSE) ocurrence in young turkey breast meat. Food Research International, 29(3-4), 363-366. http://dx.doi. org/10.1016/0963-9969(96)00020-8.

Mickelson, J. R., \& Louis, C. F. (1996). Malignant hyperthermia: excitation-contraction coupling, Ca2+ release channel, and cell Ca2+ regulation defects. Physiological Reviews, 76(2), 537-592. http://dx.doi.org/10.1152/physrev.1996.76.2.537. PMid:8618963.

Mujahid, A., Pumford, N. R., Bottje, W., Nakagawa, K., Miyazawa, T., Akiba, Y., \& Toyomizu, M. (2007). Mitochondrial oxidative damage in chicken skeletal muscle induced by acute heart stress. Journal of Poultry Science, 44(4), 439-445. http://dx.doi.org/10.2141/jpsa.44.439.

Oba, A., Almeida, M., Pinheiro, J. W., Ida, E. I., Marchi, D. F., Soares, A. L., \& Shimokomaki, M. (2009). The effect of management of transport and lairage conditions on broiler chicken breast meat quality and DOA (Death on Arrival). Brazilian Archives of Biology and Technology, 52(spe), 205-211. http://dx.doi.org/10.1590/S151689132009000700026 .

Oda, S. H. I., Nepomuceno, A. L., Ledur, M. C., Oliveira, C. N., Marin, S. R. R., Ida, E. I., \& Shimokomaki, M. (2009). Quantitative differential expression of alpha and beta Ryanodine receptor genes in PSE (Pale, Soft, Exudative) meat from two chicken lines: broiler and layer. Brazilian Archives of Biology and Technology, 52(6), 1519-1525. http://dx.doi.org/10.1590/S1516-89132009000600024.
Oliver, C. N., Ahn, B. W., Moerman, E. J., Goldstein, S., \& Stadtman, E. R. (1987). Age-related changes in oxidized proteins. The Journal of Biological Chemistry, 262(12), 5488-5491. PMid:3571220.

Olivo, R., Scares, A. L., Ida, E. I., \& Shimokomaki, M. (2001). Dietary vitamin $\mathrm{E}$ inhibits poultry PSE and improves meat functional properties. Journal of Food Biochemistry, 25(4), 271-283. http:// dx.doi.org/10.1111/j.1745-4514.2001.tb00740.x.

Purchas, R. W. (2014). Tenderness measurement. In M. Dikeman \& C. Devine (Ed.), Encyclopedia of meat science (2nd ed., pp.452-459). Oxford: Academic Press. http://dx.doi.org/10.1016/B978-0-12384731-7.00190-2.

Rosmini, M. R., Perlo, F., Pérez-Alvarez, J. Á., Pagán-Moreno, M. J., Gago-Gago, A., López-Santovena, F., \& Aranda-Catalá, V. (1996). TBA test by an extractive method applied to 'Paté. Meat Science, 42(1), 103-110. http://dx.doi.org/10.1016/0309-1740(95)00010-0. PMid:22060305.

Santos, C., Roseiro, L. C., Gonçalves, H., \& Melo, R. S. (1994). Incidence of different pork quality categories in Portuguese slaughterhouse: A survey. Meat Science, 38(2), 279-287. http://dx.doi.org/10.1016/03091740(94)90117-1. PMid:22059665.

Simões, G. S., Oba, A., Matsuo, T., Rossa, A., Shimokomaki, M., \& Ida, E. I. (2009). Vehicle thermal microclimate evaluation during Brazilian summer broiler transport and the occurrence of PSE (Pale, Soft, Exudative) meat. Brazilian Archives of Biology and Technology, 52(spe), 195-204. http://dx.doi.org/10.1590/S1516-89132009000700025.

Soares, A. L., Lara, J. A. F., Ida, E. I., Guarnieri, P. D., Olivo, R., \& Shimokomaki, M. (2002). Variation in the colour of Brazilian broiler breast fillet. In Proceedings of $48^{\text {th }}$ International Congress of meat Science and Technology (pp. 540-541). Roma: American Meat Science Association.

Soares, A. L., Olivo, R., Shimokomaki, M., \& Ida, E. I. (2004). Synergism between dietary vitamin $\mathrm{E}$ and exogenous phytic acid in prevention of warmed-over flavour development in chicken breast meat, Pectoralis major m. Brazilian Archives of Biology and Technology, 47(1), 57-62. http://dx.doi.org/10.1590/S1516-89132004000100008.

Solomon, M. B., Laack, R. L. J. M., \& Eastridge, J. S. (1998). Biophysical basis of pale, soft, exudative (PSE) pork and poultry muscle: a review. Journal of Muscle Foods, 9(1), 1-11. http://dx.doi. org/10.1111/j.1745-4573.1998.tb00639.x.

Swatland, H. J. (1995). On-line evaluation of meat. Lancaster: Technomic Publishing.

Wilhelm, A. E., Maganhini, M. B., Hernández-Blazquez, F. J., Ida, I. E., \& Shimokomaki, M. (2010). Protease activity and the ultrastructure of broiler chicken PSE (pale, soft, exudative) meat. Food Chemistry, 119(3), 1201-1204. http://dx.doi.org/10.1016/j.foodchem.2009.08.034.

Woelfel, R. L., Owens, C. M., Hirschler, E. M., Martinez-Dawson, R., \& Sams, A. R. (2002). The characterization and incidence of pale, soft, and exudative broiler meat in a commercial processing plant. Poultry Science, 81(4), 579-584. http://dx.doi.org/10.1093/ ps/81.4.579. PMid:11989759. 